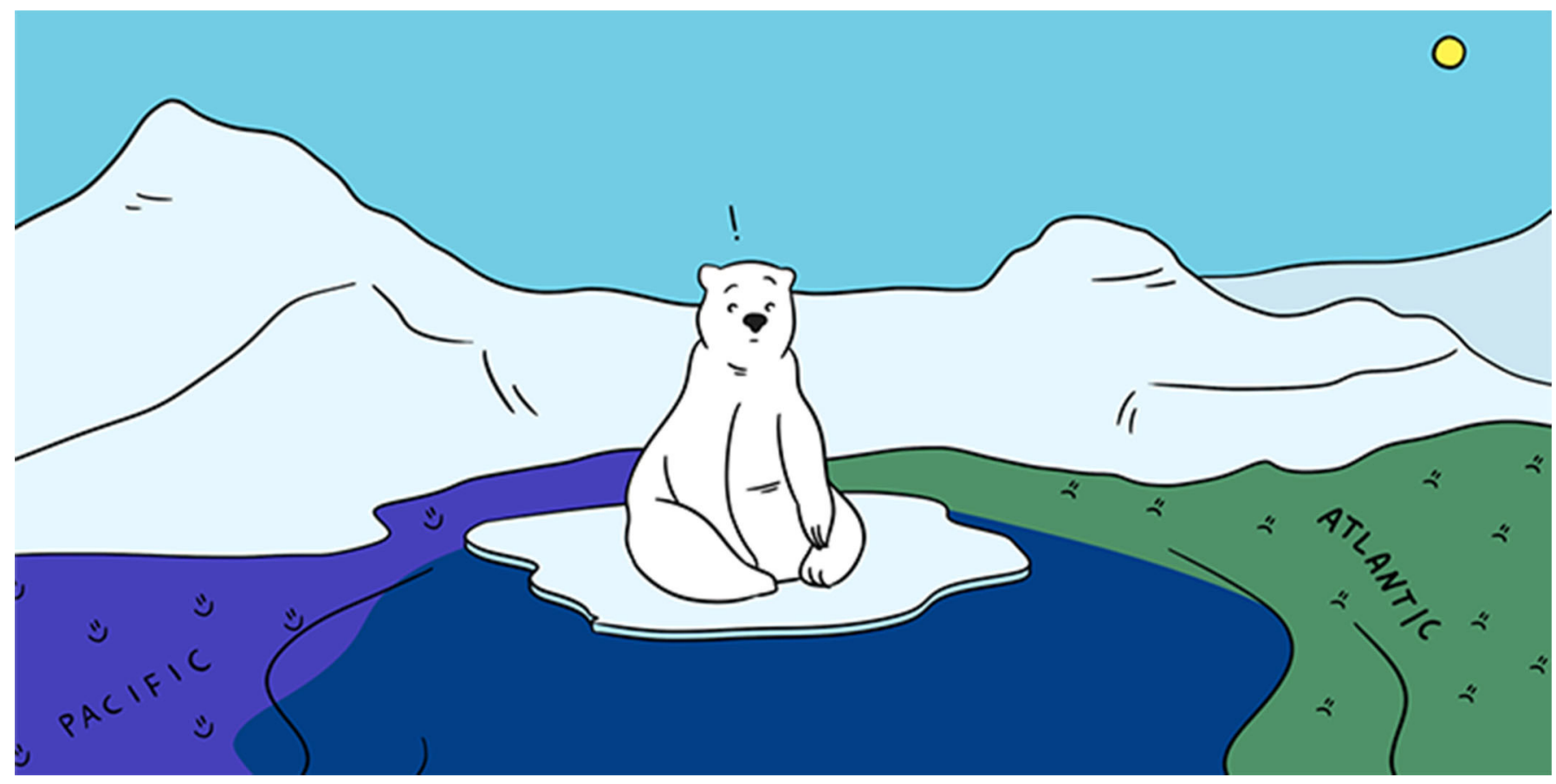

\title{
HOW NUTRITIOUS WILL THE FUTURE ARCTIC OCEAN BE?
}

\section{Pearse J. Buchanan ${ }^{1 *}$, Robyn E. Tuerena ${ }^{2}$, Alessandro Tagliabue ${ }^{1}$ and Claire Mahaffey ${ }^{1}$ \\ ${ }^{1}$ Department of Earth, Ocean and Ecological Sciences, University of Liverpool, Liverpool, United Kingdom \\ ${ }^{2}$ School of GeoSciences, University of Edinburgh, Edinburgh, United Kingdom}

YOUNG REVIEWER:

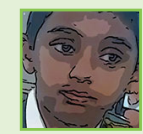

SASYAK

AGE: 12
The ocean seems the same everywhere, whether at your local beach or in the cold Arctic. But ocean properties vary greatly. Like different types of soil on land, some seawater is rich in nutrients, while others are nutrient-poor. If more nutrients are available, then more life can grow. With more life, the ocean can remove more carbon dioxide from the atmosphere and produce more fish for us to eat. Today, climate change is altering the amount of nutrients in Arctic seawater. Nutrient-rich seawater from the Pacific Ocean is flowing more quickly into the Arctic, while nutrient-poor seawater from the Atlantic Ocean is also invading. Which kind of seawater will dominate in a warmer, ice-free Arctic? Will the Arctic become rich with nutrients and support productive ecosystems, or will it become an oceanic desert? Scientists are working hard to predict what will happen in a warmer world. 


\section{GREENHOUSE GAS}

A gas that contributes to the warming of the earth known as the greenhouse effect by holding heat within the earth's atmosphere.

\section{PHYTOPLANKTON}

Tiny marine algae that form the base of marine food webs.

\section{EUPHOTIC ZONE}

The upper part of the Ocean where sunlight is available.

\section{PRODUCTIVE}

The ability to produce large amounts of something. Regarding phytoplankton, "productive" refers to high concentrations of these organisms in a given area.

\section{PHOTOSYNTHESIS}

The process of converting sunlight and carbon dioxide $\left(\mathrm{CO}_{2}\right)$ to chemical energy in the form of sugars and other carbohydrates, so that plants can grow.

\section{CLIMATE CHANGE AND THE ARCTIC OCEAN}

Earth's climate is changing. The atmosphere and the ocean are warming as humans pump carbon dioxide $\left(\mathrm{CO}_{2}\right)$ and other greenhouse gases into the atmosphere [1]. The Arctic Ocean is experiencing the most extreme change, with twice the rate of warming than the global average, rapid sea ice loss, and shifting ocean currents. We know that these changes will affect Arctic ecosystems, but how exactly? Unfortunately, scientists are still unsure how Arctic marine ecosystems will change. One of the major uncertainties comes from our inability to predict what will happen to the nutrients dissolved in Arctic seawater.

\section{WHY SHOULD WE CARE ABOUT NUTRIENTS?}

Just like soils that allow the vegetables you eat to grow, seawater has nutrients that allow phytoplankton to grow. Phytoplankton are tiny, microscopic plants that live in the euphotic zone (the sunlit surface ocean). Phytoplankton need light and nutrients to live. A nutritious ocean is one that has enough nutrients to support a productive phytoplankton community, one with an abundance of fast-growing phytoplankton.

Phytoplankton are vital for marine food webs. If enough nutrients are available for phytoplankton, these microscopic plants can support a diversity of marine animals. Productive phytoplankton communities therefore support the fisheries that almost 1 billion people rely on for food every day.

Phytoplankton also cool the planet by absorbing $\mathrm{CO}_{2}$ as they grow and perform photosynthesis, drawing this greenhouse gas out of the atmosphere and into the ocean. When phytoplankton die, the $\mathrm{CO}_{2}$ they absorbed then sinks into the deep ocean and may be buried in sediments [1]. Nutritious regions of the ocean that support productive phytoplankton communities may therefore draw $\mathrm{CO}_{2}$ out of the atmosphere, helping to cool the rapidly warming planet.

This is why we care about nutrients. By supporting productive phytoplankton communities, nutrients are important for ecosystems, fisheries, and the climate.

\section{IS THE ARCTIC A NUTRITIOUS OCEAN?}

Not all seawater is equal. In some regions of the ocean, despite receiving plenty of light for photosynthesis, nutrients are low and life is scarce. In other regions, nutrients are rich and marine life is bountiful. 


\section{Figure 1}

Satellite measurements of phytoplankton production in the Arctic Ocean. (A) Average phytoplankton production between the years 2003 to 2013 with highly productive areas in green and yellow. You can see that many places in the Arctic Ocean are productive. (B) The change in

phytoplankton production between a warm year (2012) and a cold year (2003). While there is a lot of patchiness, increases in phytoplankton production (red colors) are common around the edge of the sea ice (white area), which is melting rapidly and increasing the amount of light available for phytoplankton. You can also see that area of sea ice (white area) is smaller in (A) than in (B) because of sea ice loss since 2003.

\section{PIGMENTS}

The natural coloring matter of tissue, in this case the compounds within phytoplankton cells that absorb certain wavelengths of light for photosynthesis.
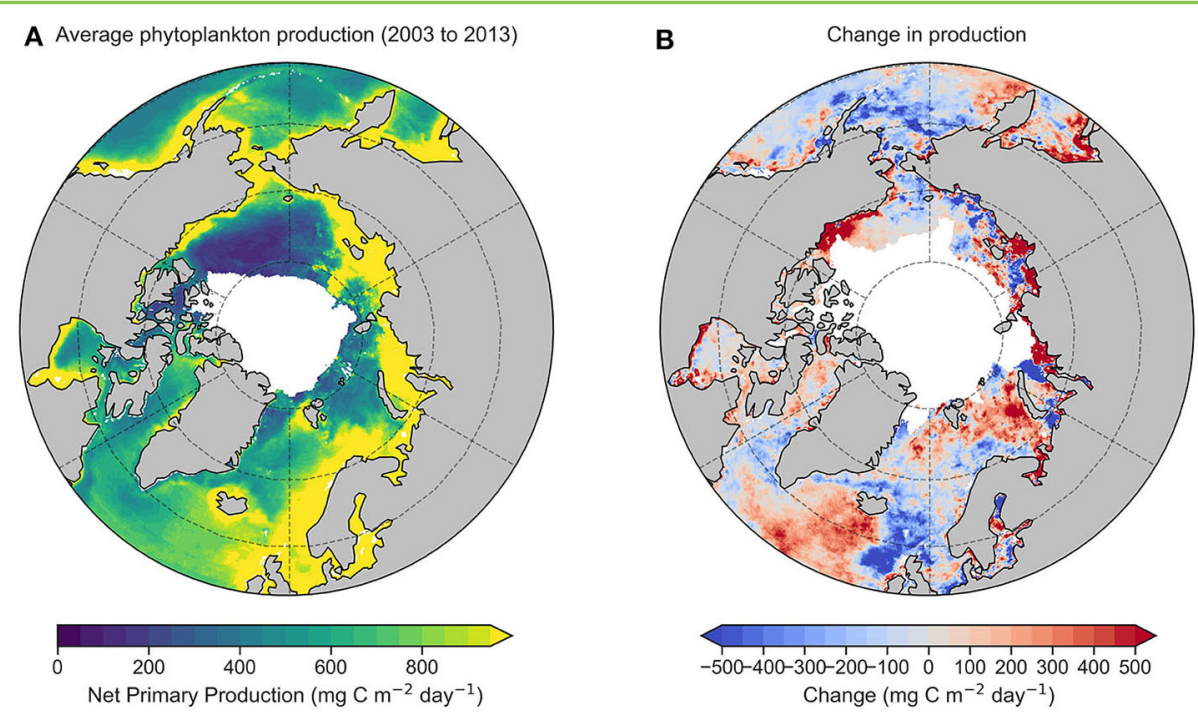

Figure 1

We can observe these "deserts" and "gardens" of the ocean using satellites, which can detect how productive phytoplankton are, all over the world. Satellites do this by measuring slight changes in the color of light that is reflected off the ocean [2]. Phytoplankton have unique pigments inside their cells that are used in photosynthesis. These pigments alter the color of light that reflects off the ocean and bounces back into space, which allows satellites to detect changes in phytoplankton. Satellite studies of the Arctic have shown that, overall, the Arctic Ocean is productive in many regions (Figure $1 \mathrm{~A}$ ), which means the Arctic waters are nutritious.

\section{RECENT CHANGES}

There is a strong possibility that the Arctic will become more productive as it warms up. As sea ice melts, more light becomes available to fuel phytoplankton growth. With more phytoplankton, the Arctic could support more fish. It could also absorb more $\mathrm{CO}_{2}$, possibly helping to draw some $\mathrm{CO}_{2}$ out of the rapidly warming atmosphere.

In fact, Arctic phytoplankton production has increased by $30 \%$ over the last few decades, with large increases where sea ice loss has been most extreme [3] (Figure 1B). However, scientists do not know if the increase in phytoplankton production will continue. The evolution of Arctic phytoplankton production will depend on whether its seawater remains nutritious. To predict how nutritious a future Arctic will be, we must understand how the Arctic receives its nutrients. To do that, we must leave the Arctic. 


\section{Figure 2}

Pacific seawater (yellow) and Atlantic seawater (purple) dominate certain areas of the Arctic Ocean. You can see the boundary between Pacific and Atlantic seawater by the solid black line. Pacific seawater is highly nutritious compared with Atlantic seawater, so you can think about the areas in yellow as being rich in nutrients. Arrows indicate the basic circulation pattern, as determined by an ocean model simulation.

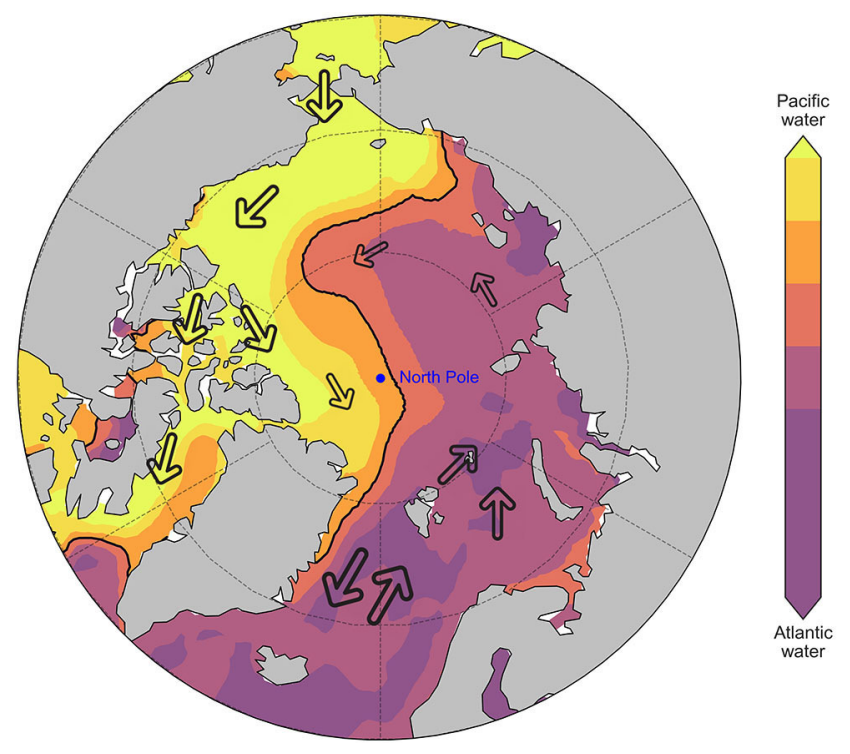

Figure 2

\section{THE ARCTIC'S OCEANIC PARTNERS: THE PACIFIC AND THE ATLANTIC}

Even though the Arctic is small, it is an important meeting place of two larger oceans: the Pacific and Atlantic (Figure 2).

The Arctic receives Pacific seawater through the Bering Strait, which is the small, shallow opening between Alaska and Russia. Meanwhile, Atlantic seawater flows into the Arctic between Greenland and Scandinavia. Pacific seawater dominates the western Arctic near Canada, while Atlantic seawater dominates the east near Europe and Russia.

Distinguishing between the Pacific and Atlantic inflows is important because the nutrient content of Pacific and Atlantic seawater differs considerably. Pacific seawater is nutrient-rich, while Atlantic seawater is nutrient-poor. The relative influence of Pacific or Atlantic seawater in the Arctic therefore determines its nutritiousness, which determines how productive phytoplankton can be.

\section{ALONG COMES CLIMATE CHANGE: A BATTLE BETWEEN THE PACIFIC AND ATLANTIC}

Today, more water is moving into the Arctic from both the Pacific and Atlantic Oceans, meaning that more Arctic water is being pushed out $[4,5]$.

So, what does this mean? First, that the properties of Arctic seawater are changing quickly. The rapidity of change threatens to alter phytoplankton communities, which could affect organisms higher up 
the food web, including marine mammals, possibly causing a total reorganization of Arctic ecosystems.

Second, we think that the contest between the Pacific and Atlantic will determine the productivity of the phytoplankton that live in the Arctic and, ultimately, the kinds of animals that live there. If the Atlantic influence continues to grow, then the Arctic may be unproductive, even with lots of light as sea ice melts. However, if the Pacific influence grows and exceeds that of the Atlantic, then the Arctic could be more nutritious and productive.

It is important to realize, however, that a possible increase in phytoplankton in the Arctic does not make climate warming a good thing. Climate warming is causing huge change throughout the Earth's biosphere, of which the Arctic is only a small part. Sea-level rise across the world could displace many people from their homes, and some ecosystems may become less productive, particularly in tropical regions. The potential increase in fish abundance and $\mathrm{CO}_{2}$ uptake in the Arctic is only a small part of a global story.

\section{SO, HOW NUTRITIOUS WILL THE ARCTIC BE IN THE FUTURE?}

The short answer is that we still do not know how nutritious the future Arctic will be. Although scientists are using satellites, ships, and computer models to monitor the Arctic Ocean [3-5], it is still difficult to predict what will happen there in the future, due to the complexities of physical and biological systems. This uncertainty makes it difficult to predict the consequences for Arctic ecosystems, its fisheries, and its contribution to reducing atmospheric $\mathrm{CO}_{2}$.

However, what is clear is that the Arctic is changing quickly, and that the nutrients supplied from its oceanic partners, the Pacific and the Atlantic, are becoming more important as sea-ice melts.

\section{REFERENCES}

1. Faust, J. C., März, C., and Henley, S. F. 2019. The carbon story of a melting Arctic. Front. Young Minds 7:136. doi: 10.3389/frym.2019.00136

2. Behrenfeld, M. J., Boss, E., Siegel, D. A., and Shea, D. M. 2005. Carbon-based ocean productivity and phytoplankton physiology from space. Glob. Biogeochem. Cycles 19:1-14. doi: 10.1029/2004GB002299

3. Arrigo, K. R., and van Dijken, G. L. 2015. Continued increases in Arctic Ocean primary production. Prog. Oceanogr. 136:60-70. doi: 10.1016/j.pocean.2015.05.002

4. Woodgate, R. A. 2018. Increases in the Pacific inflow to the Arctic from 1990 to 2015, and insights into seasonal trends and driving mechanisms from year-round Bering Strait mooring data. Prog. Oceanogr. 160:124-54. doi: 10.1016/j.pocean.2017.12.007 
5. Oziel, L., Neukermans, G., Ardyna, M., Lancelot, C., Tison, J. L., Wassmann, P., et al. 2017. Role for Atlantic inflows and sea ice loss on shifting phytoplankton blooms in the Barents Sea. J. Geophys. Res. Ocean. 122:5121-39.

doi: $10.1002 / 2016 J C 012582$

SUBMITTED: 31 October 2019; ACCEPTED: 15 June 2020;

PUBLISHED ONLINE: 24 July 2020.

EDITED BY: Christian März, University of Leeds, United Kingdom

CITATION: Buchanan PJ, Tuerena RE, Tagliabue A and Mahaffey C (2020) How Nutritious Will the Future Arctic Ocean Be? Front. Young Minds 8:93. doi: 10.3389/ frym.2020.00093

CONFLICT OF INTEREST: The authors declare that the research was conducted in the absence of any commercial or financial relationships that could be construed as a potential conflict of interest.

COPYRIGHT @ 2020 Buchanan, Tuerena, Tagliabue and Mahaffey. This is an open-access article distributed under the terms of the Creative Commons Attribution License (CC BY). The use, distribution or reproduction in other forums is permitted, provided the original author(s) and the copyright owner(s) are credited and that the original publication in this journal is cited, in accordance with accepted academic practice. No use, distribution or reproduction is permitted which does not comply with these terms.

\section{YOUNG REVIEWER}

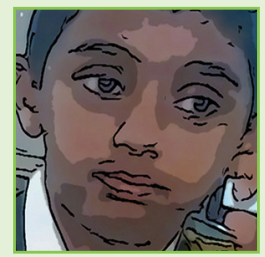

\section{SASYAK, AGE: 12}

Sasyak is a 12 years old student from India. He is an avid reader of several genres of books. He is a keen participant in quiz contests and olympiads, and is a spell bee champion. He attends football classes and enjoys cycling.

\section{AUTHORS}

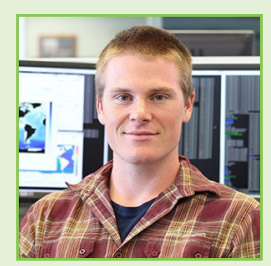

\section{PEARSE J. BUCHANAN}

I am a post-doctoral researcher at the University of Liverpool. I have always been interested in cycles and systems. My research focuses on the mechanisms that control ocean nutrient, carbon, and oxygen cycles, particularly involving the interactions between plankton and their physical and chemical environment. I use climate models to do this. *pearse.buchanan aliverpool.ac.uk

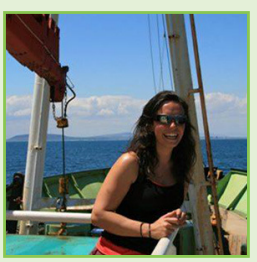

\section{ROBYN E. TUERENA}

I am a post-doctoral researcher at the University of Edinburgh. My research focuses on nutrient cycling in a range of marine environments. In particular, I study carbon and nitrogen, and how their concentrations and availability within the ocean may change in the future. I spend a lot of time in the lab and on ships using geochemical 

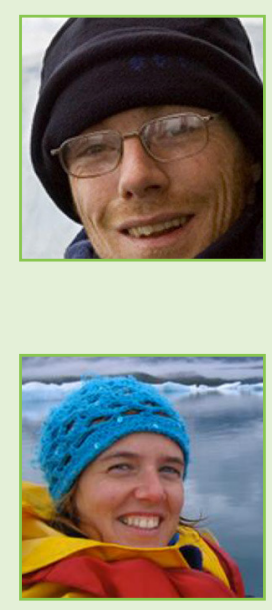

\section{CLAIRE MAHAFFEY}

I am a Professor of Ocean Sciences at the University of Liverpool. I am interested in how phytoplankton survive in a range of marine environments, how they acquire nutrients, and the role phytoplankton play in carbon and nutrient cycling and how they maintain the marine ecosystem. 